\title{
Descriptive features of Lassa fever in Bauchi, Northeastern Nigeria - a retrospective review
}

\author{
*Maigari I.M. ${ }^{1}$, Jibrin Y.B. ${ }^{1}$, Umar M.S. ${ }^{1}$, Lawal S.M. ${ }^{1}$, Gandi A.Y. ${ }^{2}$
}

\begin{abstract}
Objective: Nigeria records it largest outbreak of Lassa fever in 2018, with 416 confirmed cases by $22^{\text {nd }}$ April 2018 affecting 22 states and the Federal Capital Territory (FCT). This study determines the descriptive features of Lassa fever in Bauchi, Northeastern Nigeria.
\end{abstract}

Methods: A retrospective study that encompasses all the suspected and confirmed cases of Lassa fever managed in Abubakar Tafawa Balewa University Teaching Hospital (ATBUTH), Bauchi, between October 2016 and April 2018. Clinical notes of these patients were used to source information including sociodemographic features, clinical characteristics of the presenting illness, laboratory investigations results, working diagnosis, line of management, and treatment outcomes.

Results: A total 127 suspected cases records were reviewed out of which 27(21\%) were positive for Lassa fever Reverse Transcriptase Polymerase Chain Reaction (RT-PCR) test. Thirteen (48\%) of the confirmed cases were males and fourteen (51.9\%) females giving a male to female ratio of 1:1.08. their ages ranged from 1 to 60 years with a mean age of 27.5. Most cases were seen between October and April. Fever was the most common clinical presentation, occurring in 23 cases $(85 \%)$ at presentation. Other clinical features were headache 20 cases $(74 \%)$, bleeding 19 cases $(70 \%)$, abdominal pain 14 cases $(52 \%)$, Nausea/Vomiting 12 cases (44\%), Diarrhoea 11 cases (41\%), cough 11 cases (41\%), encephalitis 9 cases (33\%), Chest pain 8 cases (30\%), Hypotension 7 cases (26\%), Sore throat 5 cases $(19 \%)$ and Facial and or Neck swelling 3 cases (11\%). Mortality among the confirmed cases was (44.4\%) with all deaths occurring within 72 hours of presentation and had bleeding and or encephalitis as presenting symptoms.

Conclusion: Lassa fever is relatively common in Bauchi state and affects people of all age groups and sexes. Late presentation, bleeding and encephalitis were common features among mortality cases.

Keywords: Lassa Fever, clinical features, mortality, Nigeria

\footnotetext{
*Correspondence author

Maigari I. M.

http://orcid.org/0000-0003-2793-2644

Email:ibmega05@yahoo.co.uk

${ }^{1}$ Department of Internal Medicine, Abubakar Tafawa Balewa University Teaching Hospital, Bauchi, Nigeria.

${ }^{2}$ State Epidemiologist, Bauchi State Ministry of Health, Nigeria.
}

Research Journal of Health Sciences subscribed to terms and conditions of Open Access publication. Articles are distributed under the terms of Creative Commons Licence (CC BY-NC-ND 4.0). (http://creativecommons.org/licences/by-nc-nd/4.0).

http://dx.doi.org/10.4314/rejhs.v6i3.7

Res. J. of Health Sci. Vol 6(3), July/Sept., 2018 


\title{
Caractéristiques descriptives de la fièvre de Lassa à Bauchi, nord-est du Nigéria - une revue rétrospective
}

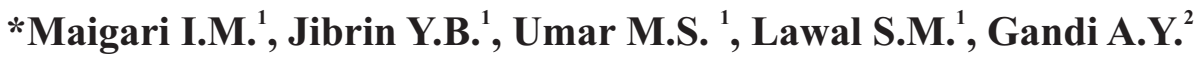

\begin{abstract}
Resume
Objectif: Le Nigeria enregistre la plus grande épidémie de fièvre de Lassa en 2018, avec 416 cas confirmés au 22 avril 2018, touchant 22 États et le territoire de la capitale fédérale (FCT). Cette étude détermine les caractéristiques descriptives de la fièvre de Lassa à Bauchi, dans le nord-est du Nigéria.

Méthodes: Une étude rétrospective qui englobe tous les cas suspects et confirmés de fièvre de Lassa pris en charge à l'hôpital universitaire Abubakar Tafawa Balewa (ATBUTH), Bauchi, entre octobre 2016 et avril 2018. Les notes cliniques de ces patients ont été utilisées pour obtenir des informations sociodémographiques, caractéristiques cliniques de la maladie, résultats des analyses de laboratoire, diagnostic fonctionnel, ligne de traitement et résultats du traitement.
\end{abstract}

Résultats: Un total de 127 cas suspects ont été examinés, parmi lesquels 27 (21\%) étaient positifs pour le test de réaction en chaîne par polymérase de transcriptase inverse (RT-PCR). Treize (48\%) des cas confirmés étaient des hommes et quatorze $(51,9 \%)$ des femmes ayant un ratio hommes / femmes de 1 : 1,08. leurs âges variaient de 1 à 60 ans avec un âge moyen de 27,5 ans. La plupart des cas ont été observés entre octobre et avril. La fièvre était la présentation clinique la plus courante, survenant dans 23 cas $(85 \%)$ lors de la présentation. Les autres caractéristiques cliniques étaient les céphalées 20 cas (74\%), les hémorragies 19 cas (70\%), les douleurs abdominales 14 cas (52\%), les nausées / vomissements 12 (44\%), la diarrhée 11 cas $(41 \%)$, la toux $11(41 \%)$, encéphalite 9 cas $(33 \%)$, douleur thoracique 8 cas $(30 \%)$, hypotension 7 cas $(26 \%)$, mal de gorge 5 cas $(19 \%)$ et gonflement du visage et du cou 3 cas $(11 \%)$. La mortalité parmi les cas confirmés était $(44,4 \%)$, tous les décès étant survenus dans les 72 heures suivant la présentation et présentant des saignements et / ou une encéphalite présentant des symptômes.

Conclusion: La fièvre de Lassa est relativement fréquente dans l'état de Bauchi et touche des personnes de tous âges et de tous sexes. La présentation tardive, l'hémorragie et l'encéphalite étaient des caractéristiques courantes parmi les cas de mortalité.

Mots-clés: Fièvre de Lassa, caractéristiques cliniques, mortalité, Nigéria

\author{
*Correspondence author \\ Maigari I. M. \\ http://orcid.org/0000-0003-2793-2644 \\ Email:ibmega05@yahoo.co.uk
}

${ }^{1}$ Department of Internal Medicine, Abubakar Tafawa Balewa University Teaching Hospital, Bauchi, Nigeria.

${ }^{2}$ State Epidemiologist, Bauchi State Ministry of Health, Nigeria.

Research Journal of Health Sciences subscribed to terms and conditions of Open Access publication. Articles are distributed under the terms of Creative Commons Licence (CC BY-NC-ND 4.0). (http://creativecommons.org/licences/by-nc-nd/4.0)

http://dx.doi.org/10.4314/rejhs.v6i3.7 


\section{INTRODUCTION}

Lassa fever (LF) is a viral haemorrhagic fever caused by the Lassa virus, an enveloped single-stranded RNA virus of the family arenaviridae (1). It is found in west and central Africa and endemic in countries like Sierra Leone, Guinea, Liberia, and Nigeria. Lassa fever was first recognised in 1969 in the town of Lassa, near Maiduguri, Northeastern, Nigeria $(2,3,4)$. A viral illness acquired by close contact with the viral natural host, a natal multimammate rat (Mastomys natalensis), an animal indigenous to most areas of sub-Saharan Africa (5), and dwells in proximity to human habitations.

Humans acquire the infection by coming in contact with urine and, or faeces of the multimammate rats and these when dried can be aerosolised and inhaled, a significant mode of transmission (6). Transmission may also occur by the rats directly contaminating human food with its saliva or excreta and by humans eating the Rats (7). Human to human transmission occurs through contacts with body fluids and may give rise to nosocomial outbreaks affecting health workers. Other routes include Sexual and transplacental transmission, transmission through breast milk is also possible due to viral shedding and high level of viraemia (8).

Between $1^{\text {st }}$ January and $21^{\text {st }}$ April 2018, Nigeria recorded 1865 suspected cases of Lassa, of which 416 were confirmed positive with 105 deaths among confirmed cases $(25.2 \%$ case fatality rate). The outbreak affected 22 of 36 states in the country, $81 \%$ from Edo state and 37 health workers affected with 8 deaths (9). The first documented case of Lassa fever in Bauchi state was in 2012 (10), since then, more cases were recorded yearly affecting seven local government areas in the southern parts of the state.

In about $80 \%$ of cases, Lassa fever is mild or has no observable symptoms and unapparent infection, diagnosed serologically, is common in endemic areas (11). The symptomatic patients present with non-specific clinical features thus; high index of suspicion is required for diagnosis (12). Major clinical features include fever, oedema of the neck and/or face, subconjunctival haemorrhage, jaundice, deafness, persistent hypotension, spontaneous abortion, bleeding from mouth, nose, rectum and/or vagina (in about $20 \%$ of cases and a late feature) (12). Other clinical features are; malaise, headache, retrosternal pain, muscle or joint pain, cough, sore throat. abdominal pain and diarrhoea.

Diagnostic investigation for Lassa fever includes; Reverse transcriptase Polymerase Chain Reaction (RT-PCR) a sensitive test for virus RNA, with almost $100 \%$ sensitivity by the third day of illness $(13,14)$. Other diagnostic methods are Vero cell cultures examined by fluorescent antibody method. ELISA can detect Lassa virus antigen and antibody in the serum. The ELISA antigen and antibody tests have $88 \%$ sensitivity and $90 \%$ specificity for the presence of the infection (15). Immunohistochemistry, performed on formalin-fixed tissue specimen can be used to make a post-mortem diagnosis.

Management of Lassa fever in Bauchi is facing challenges including; inadequate personal protective equipment, the fear of Lassa fever among health workers resulting in patient not getting optimal care and lack of diagnostic facility for Lassa and other viral haemorrhagic fevers. Samples are transported to Irrua Specialist Teaching Hospital Edo state or National Reference laboratory, Abuja for laboratory diagnosis taking average of 2-3days to for result to be available.

\section{MATERIALS AND METHODS Study setting}

The study was carried out in Abubakar Tafawa Balewa University Teaching Hospital (ATBUTH) Bauchi, Bauchi state located in northeastern Nigeria (16). The state has a population of 4,653,066 according to 2006 national census and has 20 local government areas (17). Most of the inhabitants are farmers. Bauchi state span two distinctive vegetative zones, namely Sudan savannah which covers the southern part and Sahel savannah which covers the central and northern parts (16).

This was a retrospective study that encompassed all the suspected and confirmed cases of Lassa fever managed at ATBUTH, Bauchi, between October 2016 and April 2018. ATBUTH is the only centre in Bauchi state that manages viral haemorrhagic fever cases and thus all suspected cases from within the state are referred to the centre for further evaluation and management. It is one of the tertiary health centres owned by federal government of Nigeria in the state.

Clinical notes of all patients presenting with clinically suspected Lassa fever from October 2016 to March 2018 were used to source information including sociodemographic features, clinical characteristics of the presenting illness, laboratory investigations results, working diagnosis, line of management, and treatment outcomes. Full information is not expected from 
the case note, so if not indicated in the individual case notes, certain signs and symptoms of Lassa fever were considered to be absent in a given patient and If laboratory reports were not available for a particular parameter, we assumed that the patient was not investigated for that parameter. Positive results for Lassa were confirmed by RT-PCR. Samples for RT-PCR were taken to the National reference laboratory in Abuja or Irrua specialist Hospital, Edo state for the test.

Notification information for the patients with Lassa fever was obtained from the registry of viral haemorrhagic fever cases maintained by the Infectious diseases and immunology unit of the department of internal medicine of the hospital.

Ethical clearance for the study was obtained from the Abubakar Tafawa Balewa University Teaching Hospital ethics and research committee. Data collected were stored and analyzed using statistical package for social services (SPSS) version 20.0. Simple frequency distribution of demographic variables was generated and presented as frequencies and percentages in tables and graph. Numerical values were presented as a mean and standard deviation, categorical variables were analysed by chi-square tests. Statistically, a significant association was taken at $\mathrm{p}<0.05$.

\section{RESULTS}

During the study period, a total of 127 suspected cases admitted were studied out of which $27(21 \%)$ were positive for Lassa fever RTPCR test. Thirteen (48\%) of the confirmed cases were males and fourteen (51.9\%) females giving a male to female ratio of $1: 1.08$. their ages ranged from 1 to 60 years with mean age of $27.5 \pm 13.6$. The age distribution is shown in Table 1 below. Table 2 shows the distribution of cases across the affected local government areas in Bauchi state, which were all located in the southern part of the state. One case came from the neighboring plateau state.

Two cases $(7 \%)$ had contact with confirmed cases while five $(19 \%)$ had contact with rodents, the remaining 22 (81\%) don't know if they had contact with rodents or their excreta.

Seasonal Distribution: the cases reviewed presented between the months of October 2016 to April 2018, the cases rose through November/ December to peak in January and April 2018. Table 3 summarizes the distribution of cases by month and year.

The clinical features are summarized in
Table 4. Fever was the most common clinical presentation, occurring in $23(85 \%)$ of patients at presentation. Other common clinical features were Headache 74\%, Bleeding 70\%, Abdominal pain $52 \%$, Nausea/Vomiting 44\%, Diarrhoea $41 \%$, Cough 41\%, Encephalitis 33\%, Chest pain $30 \%$, Hypotension 26\%, Sore throat $19 \%$ and Facial and or Neck swelling 11\%. Table 5 summarized the different sites of bleeding from the $70 \%$ (19) cases who had bleeding. Gastrointestinal bleeding occurred in $47 \%$ of the cases, epistaxis $32 \%$, conjunctival bleed was $11 \%$, Gingival bleeding 5\% and skin bleeding 5\%. All the 9 cases that presented with encephalitis also had bleeding.

All suspected cases of Lassa fever were started empirically on intravenous ribavirin while awaiting the outcome of Lassa RT-PCR test. The patients were screened for other common Febrile illnesses in the study area that can present in similar fashion such as Malaria and typhoid fever in addition to Lassa fever screening and coinfection addressed accordingly supportive management with intravenous fluids, blood transfusion and analgesics were also administered as indicated. RT-PCR for Lassa virus was repeated at the end of 10day course of ribavirin and returned negative.

Mortality among confirmed cases was $44.4 \%$ (12). Figure I and shows the duration of symptoms before presentation and treatment outcome respectively. All the 12 mortality cases died before the third day of admission and commencement of ribavirin (seven died on the day of presentation and 5 on the second day on admission). Average hospital stay for discharged cases was 11 days.

\section{DISCUSSION}

In this chart review case, 127 suspected cases were admitted with clinical features suggestive of Lassa fever of which 27 were confirmed positive.

The confirmed cases came from seven local government areas located in the southern part of the state and are usually seen during the harvesting period when farm products are brought home to the onset of the next rainy season with the cases disappearing with the first few showers of rain. Peak incidence was between January to April unlike the finding in Sierra Leone which shows peaks in the overlap with the wet season (May to November) (18). This could partly be due to the fact that viral aerosol stability, seems to be higher when the humidity is lower (in dry season) as explained by Stephenson 
experiment (19). The affected Local Government Areas (southern Bauchi state) are covered by distinctive vegetation zone, the Sudan savannah and belong to the western agricultural zone (16). The rains start earlier (in April) with highest recorded amount of $1300 \mathrm{~mm}$ per annum. In contrast, the northern part of the state receives the rains late, usually around June or July, and records the highest amount of $700 \mathrm{~mm}$ per annum, this is in keeping with the findings of Fichet-Calvet et al on risk maps of Lassa fever in West Africa which show clearly that Lassa fever requires a specific combination of high rainfall with a specific form of variability and seasonal timing, although the seasonal timing is different as above (20).

Most cases (59.2\%) seen belong to the age group 20-49 years, these are the active age group that are also involve in farming and related activities, therefore at risk of contact with the rodent reservoir and may have relationship with the relatively high number of cases seen among the age group 0-9years (14.8\%) who are mostly under their care. Similar prevalence among this age group was reported from other studies in Nigeria and other West African states (18.21).

Fever, headache and gastrointestinal symptoms (nausea, vomiting, abdominal pain) were the predominant symptoms observed, a similar clinical profile has been reported in patients from studies in Edo state Nigeria, Senegal and Liberia $(22,23,24)$.

The case fatality among confirmed cases was $44 \%$, this is higher than what was reported in Edo state, in South-eastern Nigeria (29\%) and in Senegal $(\%)(22,23)$. this may be due to the small number of patients studied and to late presentation. However, early presentation and early commencement of ribavirin reduced the case fatality rate. In conclusion, Lassa fever is relatively common in Bauchi state and affects people of all age groups and sexes. Late presentation, bleeding and encephalitis were common features among the mortality cases. Early commencement of ribavirin with good supportive care improves outcome.

Limitation of the study: Not all symptoms, signs and investigation results were documented in the case notes by the managing healthcare team.

Acknowledgement: We wish to thank Mallam Usman T. Chamo, medical records department and Mrs. Maryam Hussaini nurse, Lassa fever Rapid Response Team, for their assistance in data collection.

Conflict of interest: The authors declare no conflicts of interest.

\section{References}

1. Ogbu O, Ajuluchukwu E, Uneke CJ. 'Lassa fever in West African sub-region: an overview.' J Vector borne Dis 2007;44(1):1-11

2. McCormick JB, Webb PA, Krebs JW, Johnson KM, Smith ES. A prospective study of the epidemiology and ecology of Lassa fever. J Infect Dis. 1987; 155:437-444.

3. Yun NE, Walker DH. Pathogenesis of Lassa fever. Viruses 2012; 4: 2031-2048 (doi:10.3390/v4102031).

4. Carey DE, Kemp GE, White HA, Pinneo L, Andy RF, Fom AL et al: Lassa fever. Epidemiological aspects of the 1970 epidemic, Jos, Nigeria. Trans R Soc Trop Med Hyg 1972; 66:402-408.

5. Werner D. 2004. Biological resources and migration. springer. 2004 pp 363

6. Michael JB, Michael DB and Clarence J. Peters in: Bernard N. Fields et al ( $4^{\text {th }}$ edition); FieldsVirology; Lippincott Williams \& Wilkins Publishers. 2001.pp 1635-1668

7. Solomon T, Thompson G. Viral haemorrhagic fevers. In: Cook GC and Zumla AI (eds). Manson's Tropical Diseases (22nded). Saunders Elsevier, 2009; Pp763-785.

8. Greenky D, Knust B, Dziuban EJ. What Pediatricians Should Know About Lassa Virus. JAMA Pediatr. 2018;172(5):407-408. doi:10.1001/jamapediatrics.2017.5223

9. Situation report, Nigerian center for disease c o n trol a n d p r e ve nt i o n. http://ncdc.gov.ng/disease/sitreps. accessed April 27th 2018

10. Federal ministry of health. Weekly epidemiology reports, available at www.health.gov.ng/index.php/resources/report s/weekly-epidemiology-reports

11. Clinical Management of Patients with Viral Haemorrhagic fever, A Pocket Guide for the Front-line Health Worker 13 April 2014. www.who.int

12. Standard Operating Procedures for Lassa fever Case Management April 2017. Nigeria Centre for Disease Control (NCDC)

13. Demby AH, Chamberlain J, Brown DW, Clegg CS. Early diagnosis of Lassa fever by reverse transcription PCR. J Clinmicrobiol .1994; 32:2898-2903.

14. Trappier SG, Conaty AL, Farrar BB et al. Evaluation of the polymerase chain reaction for diagnosis of Lassa virus infection Am J trop Med Hyg .1993; 49:214-221

15. Lassa fever - Wikipedia, the free encyclopedia, 2018

16. Bauchi state Government. Bauchi state. 
available at www.bauchistate.gov.ng accessed 5th April 2018

17. National population commission. Bauchi state population. 2006 available at ht t p://population.gov.ng/coreactivities/surveys/dataset/2006-phc-prioritytables/

18. Richmond JK, Baglole DJ. Lassa fever: epidemiology, clinical features, and social consequences. BMJ: British Medical Journal. 2003;327(7426):1271-1275.

19. Stephenson EH, Larson EW, Dominik JW. Effect on environmental factors on aerosolinduced Lassa virus infection. J Med Virol. 1984; 14:295-303. [PubMed]

20. Fichet-Calvet E, Rogers DJ. Risk Maps of Lassa fever in West Africa. Tesh R, ed. PLoS Neglected Tropical Diseases. 2009;3(3): e388. doi: 10.1371/journal.pntd.0000388.

21. Ogbu O, Ajuluchukwu E, Uneke CJ. Lassa fever in West African sub-region: An overview. Journal of Vector Borne Diseases. 2007;44(1):1-11.

22. McCormick JB, King IJ, Webb PA, Johnson KM, O'Sullivan R, Smith ES, et al. A casecontrol study of the clinical diagnosis and course of Lassa fever. J Infect Dis 1987;155: 445-55. [PubMed]

23. Ehichioya DU, Asogun DA, Ehirmuan J, Okokhere PO, Pahmann M, Olischlagen S, Becker-Ziaja B, Gunter S, Omilabu SA. Hospital-based surveillance for Lassa fever in Edo state, Nigeria 2005-2008. Tropical medicine and international health/volume17, issue 8

24. John DF; Clinical Features of Lassa Fever in Liberia, Reviews of Infectious Diseases, Volume 11, Issue Supplement_4, 1 May 1989, Pages S $\begin{array}{llllllll}7 & 8 & 3 & - & \mathrm{S} & 7 & 8 & 9\end{array}$, https://doi.org/10.1093/clinids/11.Supplement_ 4.S783 


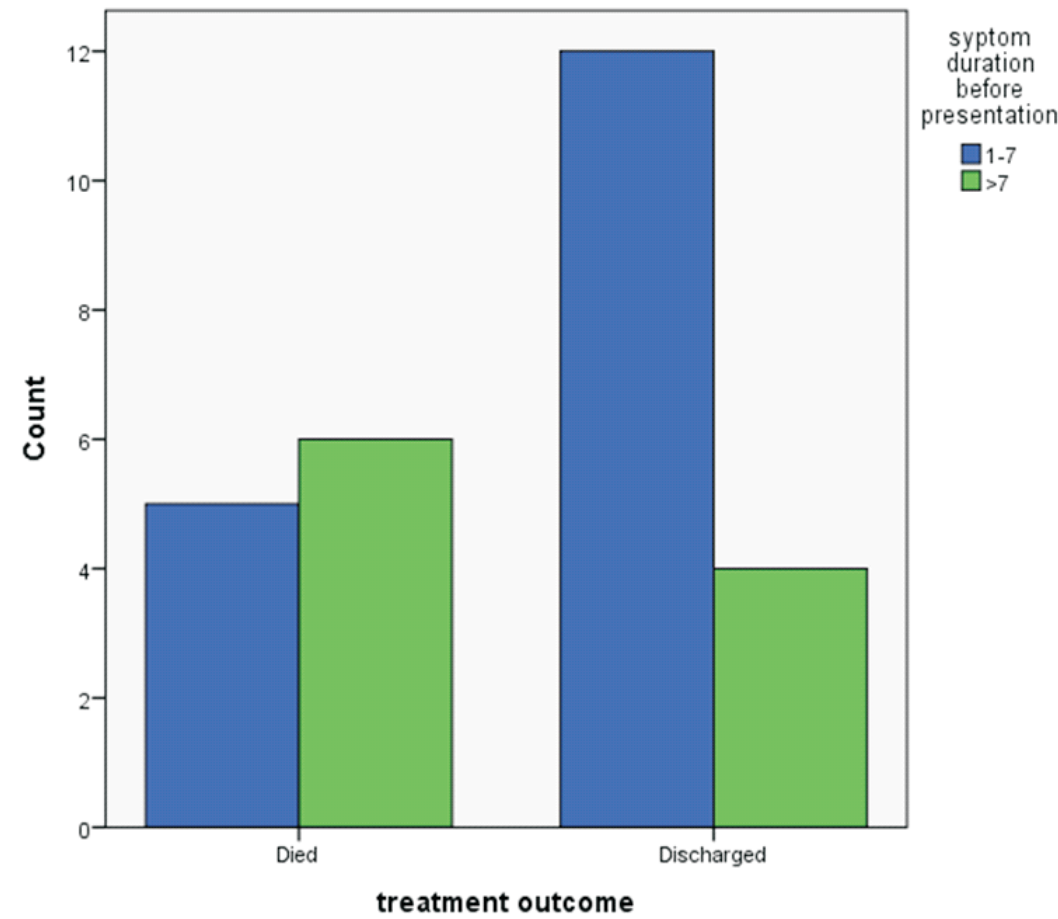

Fig. 1: A bar chart showing duration of symptom before presentation and treatment outcome. Vertical column shows the number of cases, Blue colored bars reflects cases that presents within 7 days of symptom onset while the green bar are cases presenting after seven days of symptom onset

Table 1 Age distribution of patients with Lassa fever

\begin{tabular}{lll}
\hline Age category & Frequency & Percentage \\
\hline $0-9$ & 5 & 18.5 \\
$10-19$ & 4 & 14.8 \\
$20=29$ & 6 & 22.2 \\
$30-39$ & 6 & 22.2 \\
$40-49$ & 4 & 14.8 \\
$>49$ & 2 & 7.4 \\
\hline
\end{tabular}


Table 2. Summary of distribution of Lassa fever patients across the affected local government areas in Bauchi state and the case from plateau state.

\begin{tabular}{lll}
\hline Local Government area & Frequency & Percentage \\
\hline Alkaleri & 1 & 4 \\
Bauchi & 10 & 37 \\
Bogoro & 1 & 4 \\
Dass & 3 & 11 \\
Ganjuwa & 2 & 7 \\
Tafawa Balewa & 4 & 15 \\
Toro & 5 & 19 \\
plateau & 1 & 4 \\
Total & 27 & \\
\hline
\end{tabular}

Table 3. Summary of seasonal distribution of patients with Lassa fever in Bauchi

\begin{tabular}{lll}
\hline Month & Frequency & Percentage (\%) \\
\hline October, 2017 & 2 & 7 \\
November, 2017 & 2 & 7 \\
December, 2017 & 3 & 11 \\
January & 7 & 26 \\
February & 4 & 15 \\
March & 9 & 33 \\
Total & 27 & \\
\hline
\end{tabular}

Table 4. Summary of clinical profiles of Lassa fever cases

\begin{tabular}{lll}
\hline Clinical feature & Frequency & Percentage (\%) \\
\hline Fever & 23 & $85 \%$ \\
Headache & 20 & $74 \%$ \\
Bleeding & 19 & $70 \%$ \\
Abdominal Pain & 14 & $51 \%$ \\
Nausea/Vomiting & 12 & $44 \%$ \\
Diarrhoea & 11 & $41 \%$ \\
Cough & 11 & $41 \%$ \\
Encephalitis & 9 & $33 \%$ \\
Chest pain & 8 & $30 \%$ \\
Hypotension & 7 & $26 \%$ \\
Sore throat & 5 & $19 \%$ \\
Facial or neck & 3 & $11 \%$ \\
swelling & & \\
\hline
\end{tabular}

Table 5: Summary of sites of bleeding in Lassa fever cases

\begin{tabular}{cll}
\hline Site of Bleeding & Frequency & Percentage $(\%)$ \\
\hline Epistaxis & 8 & 32 \\
Gastrointestinal & 6 & 47 \\
Gingival bleed & 1 & 5 \\
Conjunctival & 7 & 11 \\
Skin & 1 & 5 \\
\hline
\end{tabular}

